\title{
The mandibular rehabilitation multidisciplinary after mandibulectomy
}

\author{
Reabilitação mandibular multidisciplinar após mandibulectomia \\ Rehabilitación mandibular multidisciplinar tras mandibulectomía
}

Received: 01/10/2022 | Reviewed: 01/13/2022 | Accept: 01/17/2022 | Published: 01/18/2022

\author{
Beethoven Estevão Costa \\ ORCID: https://orcid.org/0000-0002-4274-2833 \\ Universidade Estadual Paulista "Júlio de Mesquita Filho", Brazil \\ E-mail: beethoven.e.costa@unesp.br \\ Gabriel Lucio Calazans Duarte \\ ORCID: https://orcid.org/0000-0002-0257-1494 \\ University of São Paulo, Brazil \\ E-mail: gabriel7duarte@gmail.com \\ Cleuber Rodrigo Bueno \\ ORCID: https://orcid.org/0000-0002-8963-8793 \\ University of São Paulo, Brazil \\ E-mail: cleuberrsbueno@gmail.com \\ Nataira Regina Momesso \\ ORCID: https://orcid.org/0000-0002-5537-2448 \\ Universidade Estadual Paulista "Júlio de Mesquita Filho", Brazil \\ E-mail: natairar@gmail.com \\ Carlos Nicolau Feitosa Albuquerque Lima Babadopulos \\ ORCID: https://orcid.org/0000-0002-4106-1542 \\ University of São Paulo, Brazil \\ E-mail: nicolaubabadopulos@gmail.com \\ Paulo Domingos Ribeiro Junior \\ ORCID: https://orcid.org/0000-0003-0956-2395 \\ Instituto Odontológico de Cirurgia e Prótese, Brazil \\ E-mail: paulodomingosribeirojunior@gmail.com
}

\begin{abstract}
Current treatment of odontogenic tumors (OT) ranges from simple enucleation by curettage or segmental resection. But the treatment does not stop here, we need to think about the rehabilitation of the patients. The Mandibular reconstruction can begin immediately postoperatively, but the delayed reconstruction can be the best option for treatment, because of the high risk of recurrence in some OT, but it is always a challenge. The aim of this study is to describe the approach of a case of mandibular odontogenic myxoma and your total rehabilitations. The segmental hemi-mandibulectomia was performed with an intraoral. After 2 year the iliac crest grafting to intraoral approach was done and after 6 months osseointegrated implants were put and the immediate load with hybrid prostheses was done. After 2 years of complete rehabilitation we can consider that this sequence looks like to be a good form to become social, psychological, esthetic and function in the patients.
\end{abstract}

Keywords: Myxoma; Mandibular reconstruction; Anterior iliac crest.

\section{Resumo}

O tratamento atual de tumores odontogênicos (TO) varia de simples enucleação por curetagem ou ressecção segmentar. Mas o tratamento não para por aqui, precisamos pensar na reabilitação dos pacientes. A reconstrução mandibular pode começar imediatamente no pós-operatório, mas a reconstrução tardia pode ser a melhor opção de tratamento, devido ao alto risco de recorrência em alguns TO, mas sempre é um desafio. O objetivo deste estudo é descrever a abordagem de um caso de mixoma odontogênico mandibular e suas reabilitações totais administradas. A hemi-mandibulectomia segmentar foi realizada por via intraoral. Após 2 anos foi feito enxerto de crista ilíaca para acesso intraoral e após 6 meses foram colocados implantes osseointegrados e realizada carga imediata com próteses híbridas. Após 2 anos de reabilitação completa podemos considerar que esta sequência parece ser uma boa forma de se tornar social, psicológico, estético e funcional dos pacientes.

Palavras-chave: Mixoma; Reconstrução mandibular; Crista ilíaca anterior.

\section{Resumen}

El tratamiento actual de los tumores odontogénicos (OT) varía desde una simple enucleación mediante curetaje o resección segmentaria. Pero el tratamiento no se detiene ahí, hay que pensar en la rehabilitación de los pacientes. La reconstrucción mandibular puede comenzar inmediatamente después de la operación, pero la reconstrucción tardía 
puede ser la mejor opción de tratamiento debido al alto riesgo de recurrencia en algunos OT, pero siempre es un desafío. El objetivo de este estudio es describir el abordaje de un caso de mixoma odontogénico mandibular y su rehabilitación total administrada. Se realizó hemimandibulectomía segmentaria por vía intraoral. A los 2 años se realizó injerto de cresta ilíaca para acceso intraoral y a los 6 meses se colocaron implantes osteointegrados y se realizó carga inmediata con prótesis híbridas. Después de 2 años de rehabilitación completa, podemos considerar que esta secuencia parece ser una buena forma de hacer que los pacientes sean sociales, psicológicos, estéticos y funcionales.

Palabras clave: Reconstrucción mandibular; Mixoma; Crista ilíaca anterior.

\section{Introduction}

Odontogenic myxoma $(\mathrm{OM})$ is a benign mesenchymal tumor, characterized by stellate and spindle -shaped cells, which may contain odontogenic epithelium, (Chrcanovic e Gomez., 2018) the World Health Organization (WHO) classified as tumor of ectomesenchyma origin with or without odontogenic epithelium (Pindborg et al., 1971).

Current treatment of odontogenic myxoma ranges from simple enucleation, peripheral ostectomy, curettage to segmental resection and hemimandibulectomy (Adamo et al., 1980; Dodson et al., 1987; Kawase-Koga et al. 2014; Shin et al., 2020;), but surgical resection is the most appropriate treatment for these cases,4 (Takahashi et al. 2018) because the recurrence rates are high, at around 25\% (Rocha et al. 2009).

Segmental mandibular defect after tumor surgery can be reliably reconstructed using pedicled myocutaneous flaps, free grafts including particulate or cortical bone, alloplasts, pedicled osteomyocutaneous flaps, and free vascularized bone flaps. (Kumar et al. 2016; Shin et al., 2020)

The aim of this study was to describe the long-term outcome of a case of mandibular odontogenic myxoma managed by segmental resection, with an intraoral approach followed by iliac crest grafting and rehabilitation with dental implants.

\section{Methodology}

This clinical case report is a descriptive observational study, which aims to discuss the treatment proposed by the authors in comparison to that found in the literature. (Adamo et al., 1980). The case was conducted in accordance with clinical and professional ethics. The patient reported in the study has a personal data sheet and anamnesis, where he authorized the use of images, clinical, radiographic and socioeconomic data for educational and research purposes, and with that he signed the Free and Informed Consent Term and the Free Consent Term and enlightened. Consent to Participation of the Person as a Subject, which have been duly read and explained.

\section{Case Report}

A 34-year-old female patient was referred to the Department of Oral-Maxillofacial Surgery, in the University of Sacred Heart, reported with a chief complaint of painless swelling over right cheek region. Clinical examination showed facial asymmetric in the right side.(Figure 1) On the intraoral examination the lesion extended from the mesial of the canine to distal the first molar. A panoramic radiograph revealed an extensive radiolucent and multilocular area with imprecise borders that extended from the mesial of the canine to distal the first mandibular molar and exhibited a "soap bubble" appearance (Figure 2). Cone-beam computed tomographic (CT) revealed a multilocular hypodense image involving the roots of the teeth 41 to 47 without displacement and root resorption, expansion of the vestibular cortical and tapering of the lingual cortical near the mandibular canal with integrity of the base of the mandible.(Figure 3) Based on the clinical and radiographic findings, the differential diagnosis included: ameloblastoma, myxoma and central giant cell lesion. To confirm diagnosis, incisional biopsy was done under local anesthesia and sent for histopathological examination. The result confirm a odontogenic myxoma.(Figure $4 \mathrm{a}$ e $4 b)$ 
Research, Society and Development, v. 11, n. 2, e8711225550, 2022 (CC BY 4.0) | ISSN 2525-3409 | DOI: http://dx.doi.org/10.33448/rsd-v11i2.25550

Figure 1: Clinical examination showed facial asymmetric in the right side.

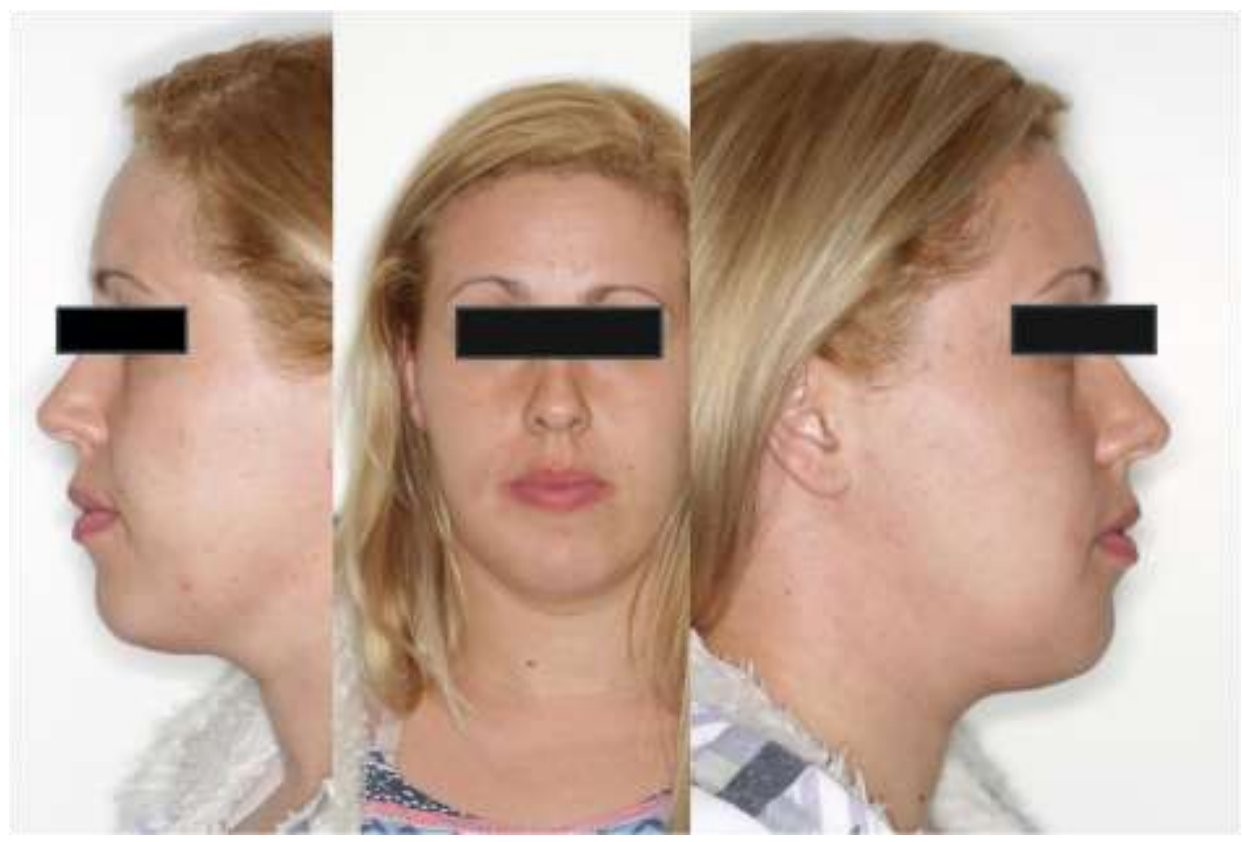

Source: Authors

Figure 2: A panoramic radiograph revealed an extensive radiolucent and multilocular area with imprecise borders that extended from the mesial of canine to distal the first mandibular molar and exhibited a "soap bubble" appearance.

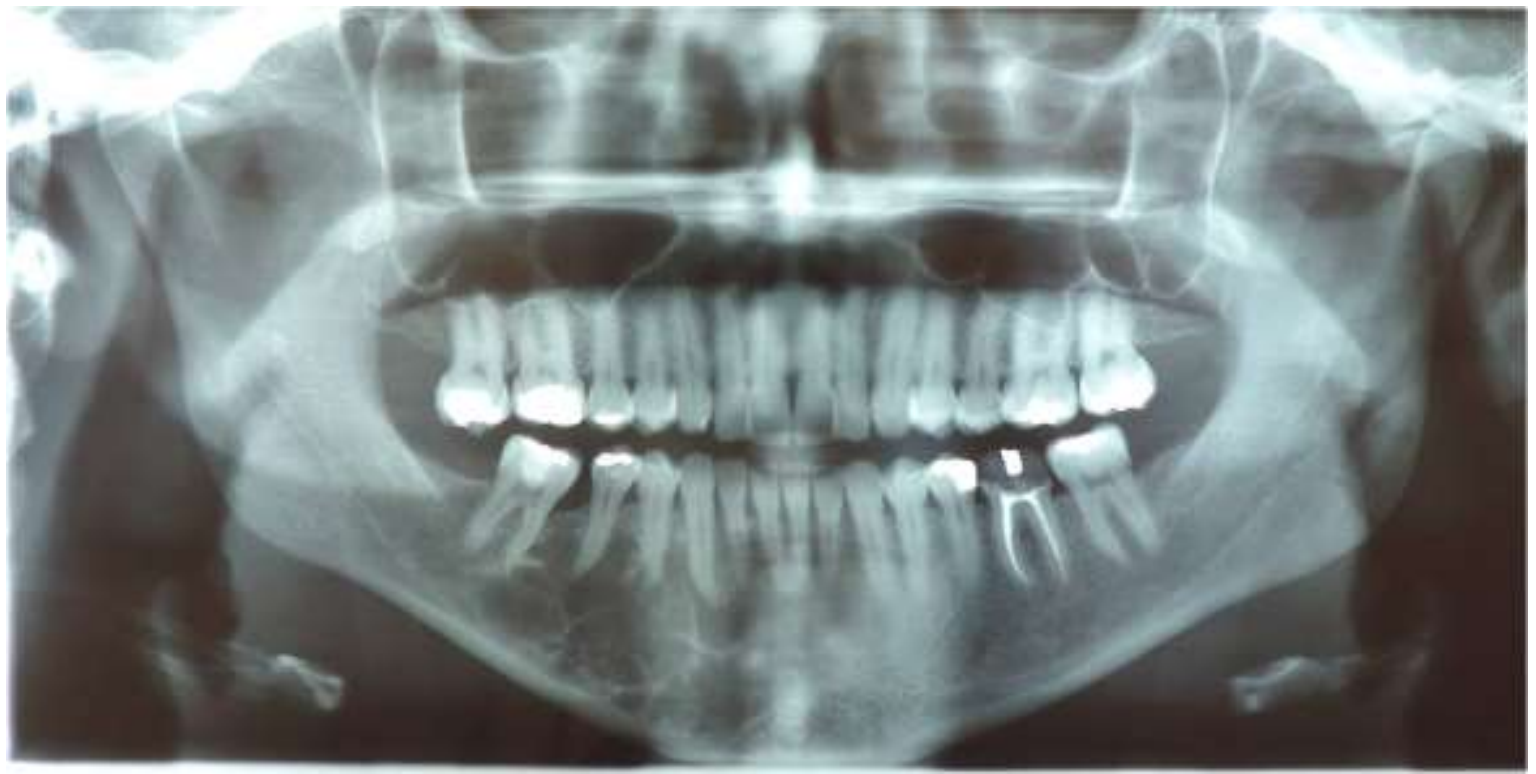

Source: Authors 
Research, Society and Development, v. 11, n. 2, e8711225550, 2022

(CC BY 4.0) | ISSN 2525-3409 | DOI: http://dx.doi.org/10.33448/rsd-v11i2.25550

Figure 3:Cone-beam computed tomographic (CT) revealed a multilocular hypodense image involving the roots of the teeth 41 to 47 without displacement and root resorption, expansion of the vestibular cortical and tapering of the lingual cortical near the mandibular canal with integrity of the base of the mandible.

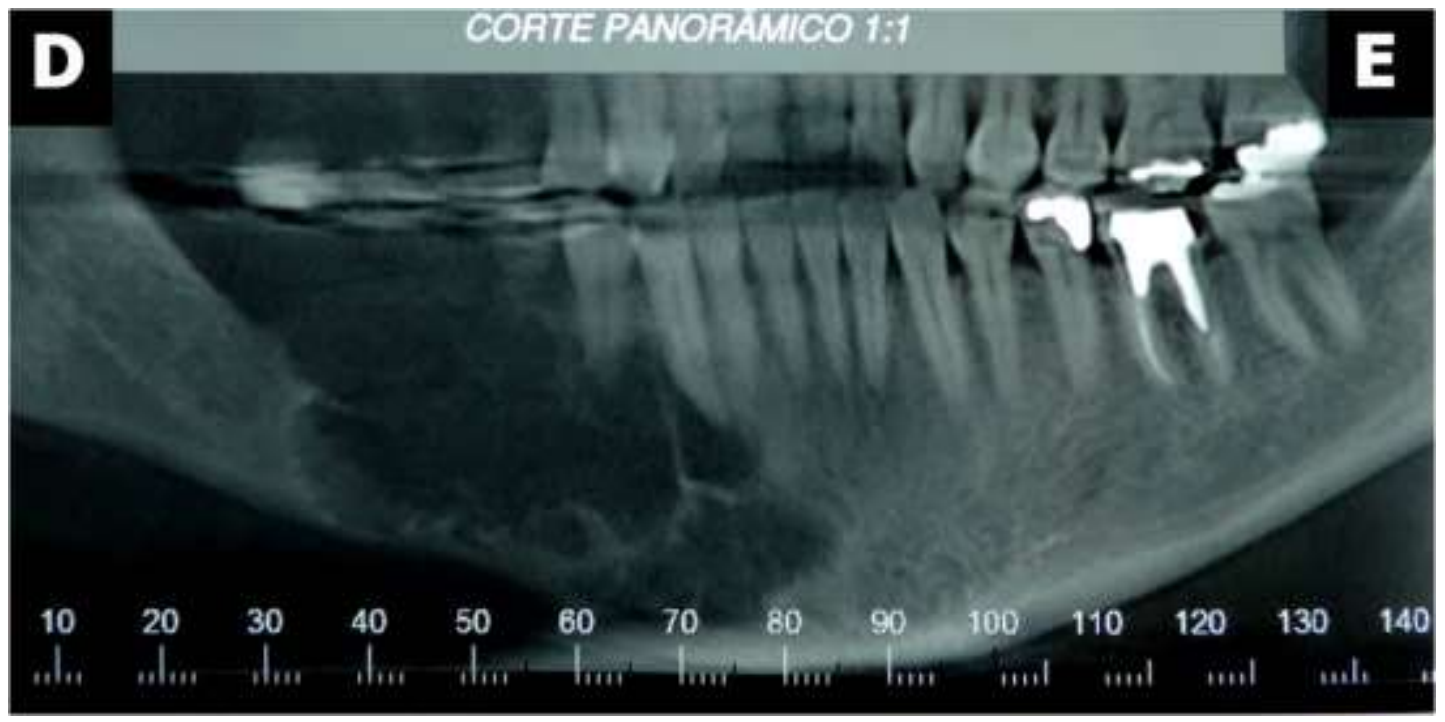

Source: Authors

Figure 4a/4b: The result of histological, confirm a odontogenic myxoma.
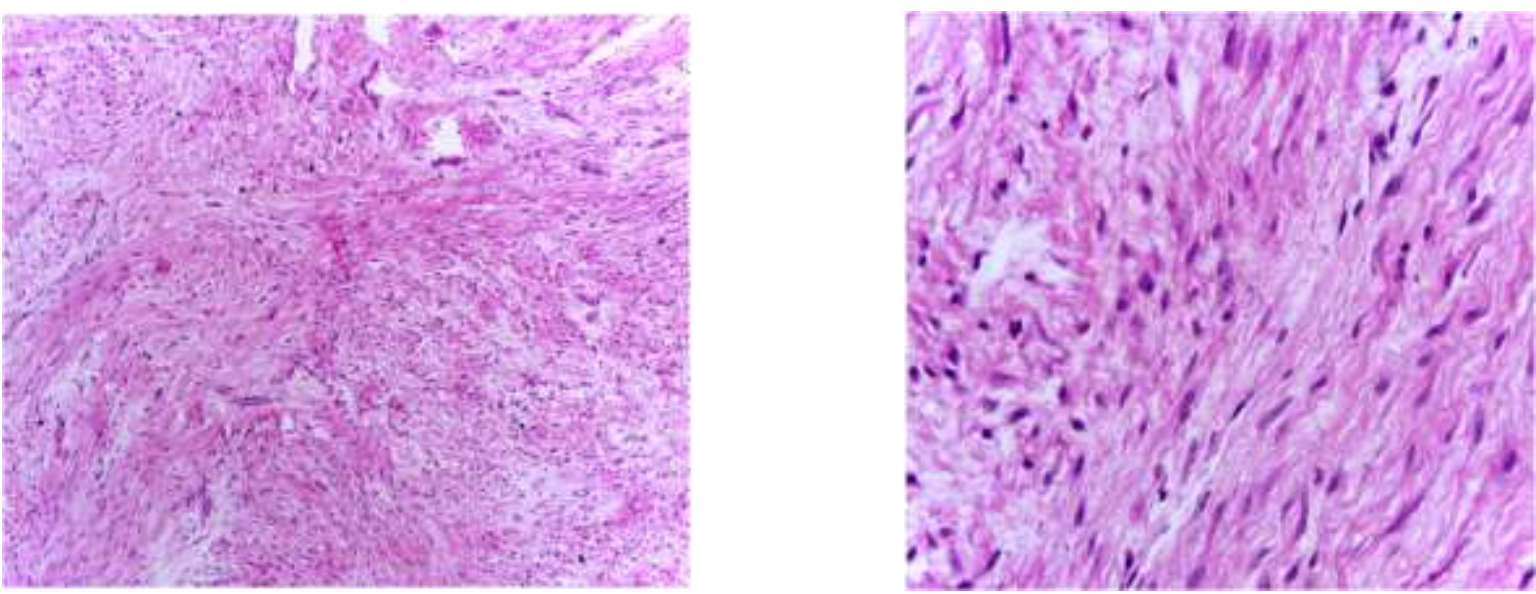

Source: Authors

Based on the clinical, radiographic and histopathological results, a treatment plan was performed consisting of marginal resection with intraoral access, mandibular reconstruction with autogenous iliac crest graft and oral rehabilitation with implants.

A biomodel is then required to allow pre-folding of the reconstruction plate, allowing a more conservative access and treatment to marginal resection preserving the mandibular base and the lingual cortical with installation of pre-folded reconstruction plate 2.4 using an esteolitographic model (Figure 5) 
Research, Society and Development, v. 11, n. 2, e8711225550, 2022 (CC BY 4.0) | ISSN 2525-3409 | DOI: http://dx.doi.org/10.33448/rsd-v11i2.25550

Figure 5: A biomodel is then required to allow pre-folding of the reconstruction plate.

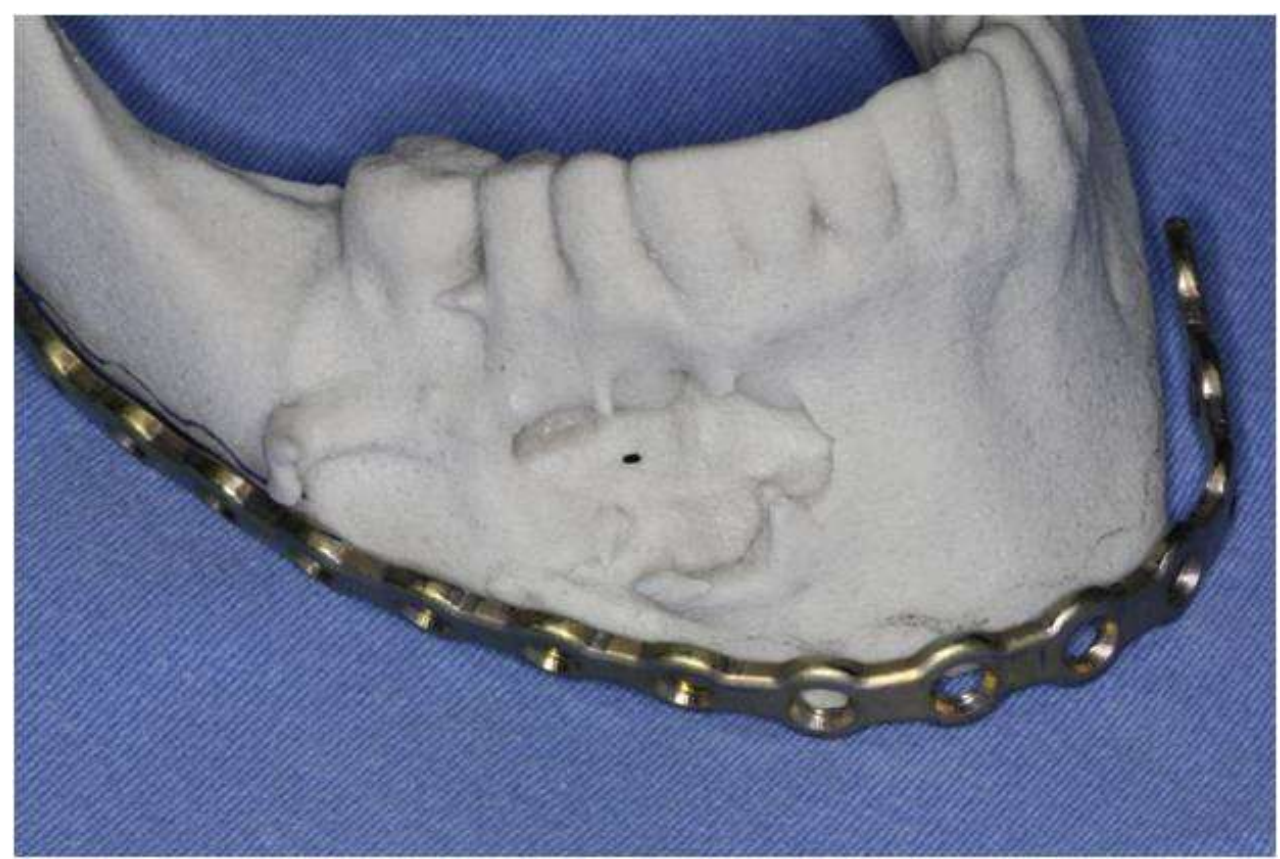

Source: Authors

After a clinical and radiographic follow-up of 2 years and without recurrence of the lesion, it was submitted to mandibular reconstruction with a block bone graft of the anterior iliac crest.(Figure 6)

Figure 6: Mandibular reconstruction with a block bone graft of the anterior iliac crest.

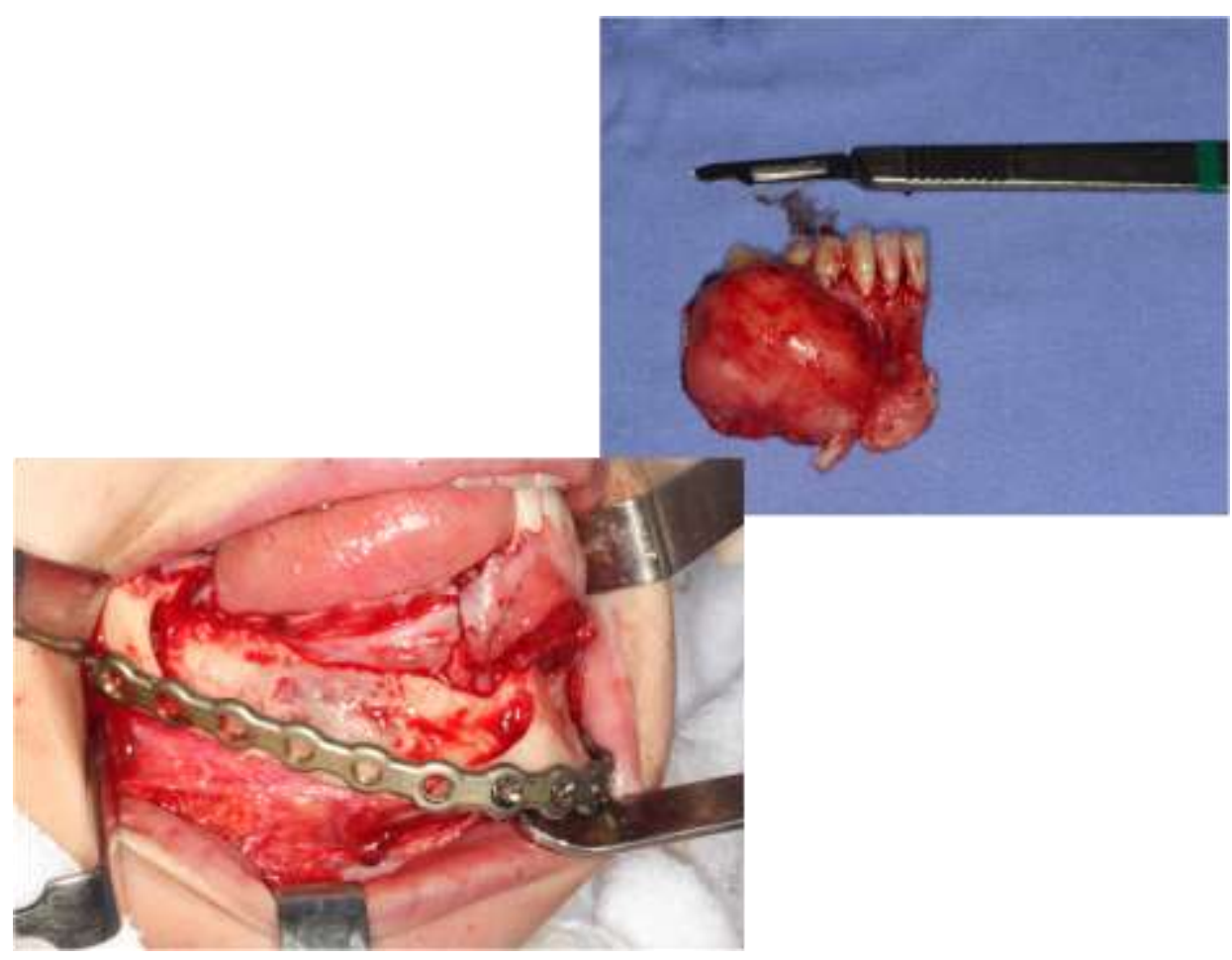

Source: Authors

With clinical and radiographic control of the graft, the preliminary preparation for the preparation of a surgical guide 
Research, Society and Development, v. 11, n. 2, e8711225550, 2022

(CC BY 4.0) | ISSN 2525-3409 | DOI: http://dx.doi.org/10.33448/rsd-v11i2.25550

for the planning of 4 Straumann BLT implants was started after 6 months, and rehabilitation with implant-supported prosthesis was performed. (Figure 7)

Figure 7: Rehabilitation with implant-supported prosthesis was performed

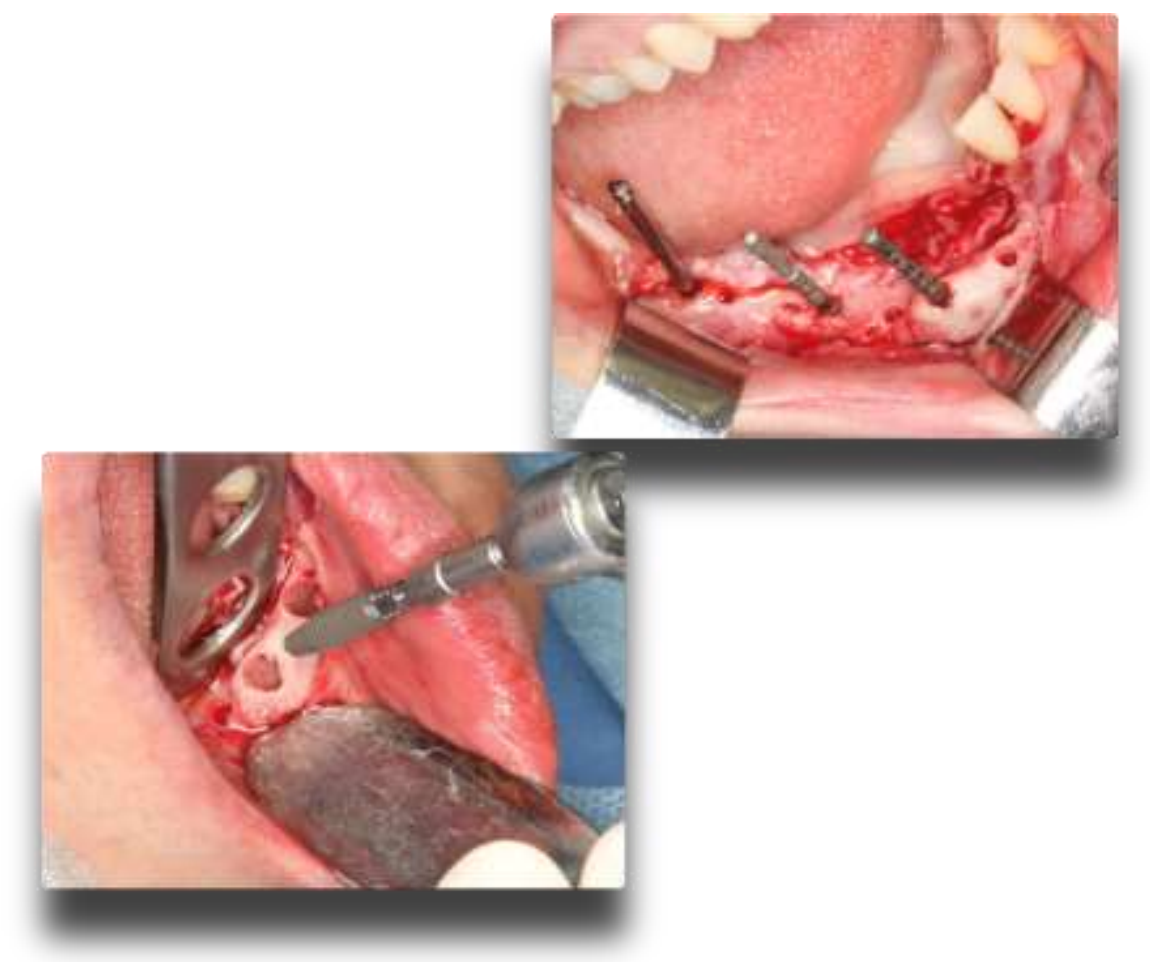

Source: Authors

In 4 years of follow-up of tumor resection surgery and 2 years of rehabilitation, the patient has a good masticatory function, with no complaints of pain and with aesthetic-functional results.(Figure 8)

Figure 8: Follow-up of tumor resection surgery and 2 years of rehabilitation

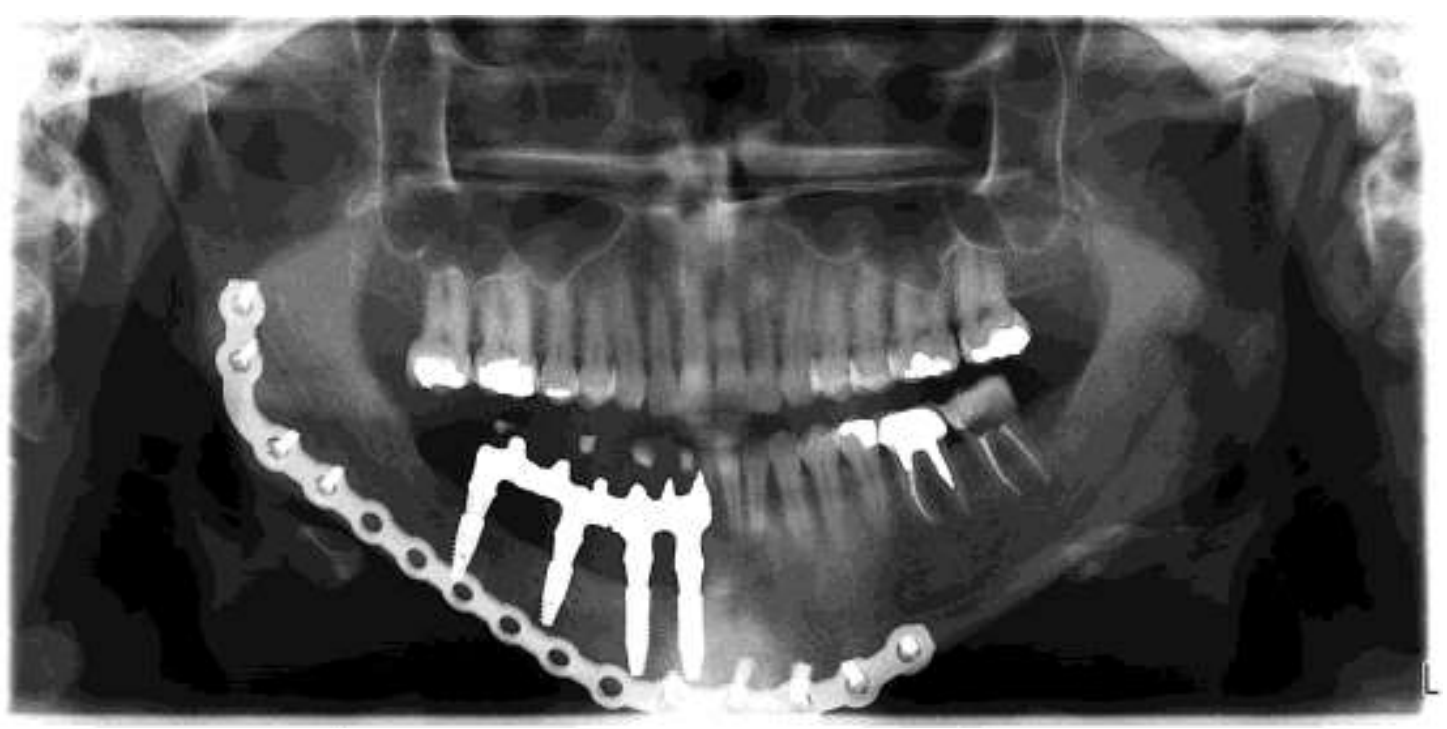

Source: Authors 


\section{Discussion}

Odontogenic myxoma is a rare benign tumor derived from embryonic mesenchymal tissue associated with odontogenesis, (Jindwani et al., 2013) was first described in 1947 by Thoma and Goldman (Kawase-Koga et al., 2014). In most studies, the mandible appears to be more frequently affected than the maxilla (Kaffe et al., 1997; Jindwani et al., 2013) Female predilection is a common feature, reported in several studies, so in the present case, a 34-year-old female patient was reported, which is consistent with the other reported cases.

The radiological appearance is a "tennis racquet strings"logical " or of a "soap bubble" or show uni- or multi- locular "honey-panel" pattern, with cortical expansion and dental displacemen (Rotenberg et al., 2004; Peltola et al., 1994). Our patient reported no symptoms in the right mandibular area; however, panoramic radiography revealed an extensive radiolucent and multilocular area with imprecise borders that extended from the mesial of the mandibular canine to the distal first lower molar.

The first option for the treatment of odontogenic myxoma is surgery, but there is a consensus on the best approach option (Kawase-Koga et al. 2014). Conservative treatment was defined as marginal resection, enucleation, and curettage ( Cuestas e Carnero et al ., 1988) radical treatment was defined as segmental or block resection, and hemimandibulectomy with reconstruction. (Kawase-Koga et al., 2014) Research shows that conservative treatments for minor lesions and radical interventions for large lesions show better prognosis, with a lower risk of recidivism and greater preservation of vital structures (Adebayo et al., 2005; Fernandes et al., 2005; Li et al., 2006).

In agreement with the available literature, the tumor was removed by en marginal resection and no recurrence was reported even after four years of the surgery. Prognosis in the present case after excision was excellent in this four year followup period. The treatment performed with intraoral approach represented a less morbid intervention, the possibility of intraoral access, a shorter hospitalization time, and not interfering with facial nerve ( Higo et al., 2015)

Reconstruction of mandibular defects can begin immediately postoperatively, but delayed reconstruction is the best option for treatment, because of the high risk of recurrence. The immediate mandibular reconstruction using a reconstruction plate and second surgery with delayed autogenous bone graft are advantageous to decrease the possibility of facial deformity and overcome the psychological effects. Full function and rapid dental rehabilitation are expected in this reconstruction (Sudhakar et al., 2017)

After a clinical and radiographic follow-up of 2 years and without recurrence of the lesion, it was submitted to mandibular reconstruction with a block bone graft of the anterior iliac crest. The anterior iliac crest is the best option because provides an adequate harvest of corticocancellous, cancellous, or bicortical grafts for reconstruction of various osseous defects in the maxillofacial region with least morbidity and should be considered as a major reservoir of bone for bony reconstructive procedures (Sudhakar et al., 2017)

\section{Conclusion}

The success of the clinical management of this case after the 4-year follow-up is due to the correct treatment decision for odontogenic myxoma, to minimize the risk of recurrence and, at the same time, adopt a less invasive surgical approach, returning the patient a good masticatory function and aesthetics.

\section{References}

Adamo, A. K., Locricchio, R. C., \& Freedman, P. (1980). Myxoma of the mandible treated by peripheral ostectomy and immediate reconstruction: report of case. Journal of Oral Surgery (American Dental Association: 1965), 38(7), 530-533.

Adebayo, E. T., Ajike, S. O., \& Adekeye, E. O. (2005). A review of 318 odontogenic tumors in Kaduna, Nigeria. Journal of oral and maxillofacial surgery, 63(6), 811-819. 
Research, Society and Development, v. 11, n. 2, e8711225550, 2022 (CC BY 4.0) | ISSN 2525-3409 | DOI: http://dx.doi.org/10.33448/rsd-v11i2.25550

Chrcanovic, B. R., \& Gomez, R. S. (2019). Odontogenic myxoma: an updated analysis of 1,692 cases reported in the literature. Oral diseases, 25(3), 676-683. Cuestas-Carnero, R., Bachur, R. O., \& Gendelman, H. (1988). Odontogenic myxoma: report of a case. Journal of oral and maxillofacial surgery, 46(8), 705709.

Dodson, T. B., \& Smith, R. A. (1987). Mandibular reconstruction with autogenous and alloplastic materials following resection of an odontogenic myxoma. International Journal of Oral \& Maxillofacial Implants, 2(4).

Fernandes, A. M., Duarte, E. C. B., Pimenta, F. J. G. S., Souza, L. N., Santos, V. R., Mesquita, R. A., \& de Aguiar, M. C. F. (2005). Odontogenic tumors: a study of 340 cases in a Brazilian population. Journal of oral pathology \& medicine, 34(10), 583-587.

Jindwani, K., Nevaskar, V., \& Agrawal, D. (2013). Odontogenic Myxoma of Maxilla: Management and Follow-up of A Rare Case.

Higo, M., Kasamatsu, A., Ogawara, K., Shiiba, M., Uzawa, K., \& Tanzawa, H. (2015). A case of a rapidly expanding odontogenic myxoma of the mandible. Oral Science International, 12(1), 22-26.

Huang, X., Liu, J., Wang, H., Zhu, H., Li, Z., \& Teng, L. (2014). Clinical research of resection of mandibular benign tumors and primary reconstruction with autogenous bone graft via an intraoral approach. Zhongguo xiu fu chong jian wai ke za zhi= Zhongguo xiufu chongjian waike zazhi= Chinese journal of reparative and reconstructive surgery, 28(2), 192-196.

Li, T. J., Sun, L. S., \& Luo, H. Y. (2006). Odontogenic myxoma: a clinicopathologic study of 25 cases. Archives of pathology \& laboratory medicine, 130(12), 1799-1806.

Kaffe, I., Naor, H., \& Buchner, A. (1997). Clinical and radiological features of odontogenic myxoma of the jaws. Dentomaxillofacial Radiology, 26(5), 299303.

Kawase-Koga, Y., Saijo, H., Hoshi, K., Takato, T., \& Mori, Y. (2014). Surgical management of odontogenic myxoma: a case report and review of the literature. BMC research notes, 7(1), 1-7.

Kumar, B. P., Venkatesh, V., Kumar, K. J., Yadav, B. Y., \& Mohan, S. R. (2016). Mandibular reconstruction: overview. Journal of maxillofacial and oral surgery, 15(4), 425-441.

Peltola, J., Magnusson, B., Happonen, R. P., \& Borrman, H. (1994). Odontogenic myxoma-a radiographic study of 21 tumours. British Journal of Oral and Maxillofacial Surgery, 32(5), 298-302.

Pindborg, J. J. (1971). Histological typing of odontogenic tumours, jaw cysts, and allied lesions. International histological classification of tumors, 1-44.

Rocha, A. C., Gaujac, C., Ceccheti, M. M., Amato-Filho, G., \& Machado, G. G. (2009). Treatment of recurrent mandibular myxoma by curettage and cryotherapy after thirty years. Clinics, 64(2), 149-152.

Rotenberg, B. W., Daniel, S. J., Nish, I. A., Ngan, B. Y., \& Forte, V. (2004). Myxomatous lesions of the maxilla in children: a case series and review of management. International journal of pediatric otorhinolaryngology, 68(10), 1251-1256.

Sudhakar, K. N. V., Mohanty, R., \& Singh, V. (2017). Evaluation of donor site morbidity associated with iliac crest bone harvest in oral and maxillofacial, reconstructive surgery. Journal of clinical and diagnostic research: JCDR, 11(6), ZC28.

Shin, H. S., Kim, M. S., Kim, B. H., Lim, H. J., Kim, B. C., \& Lee, J. (2020). Reconstruction of Mandibular Defects With Bone Marrow-Derived Stem Cells in Odontogenic Myxoma. Journal of Craniofacial Surgery, 31(3), e236-e239.

Takahashi, Y., Tanaka, K., Hirai, H., Marukawa, E., Izumo, T., \& Harada, H. (2018). Appropriate surgical margin for odontogenic myxoma: a review of 12 cases. Oral surgery, oral medicine, oral pathology and oral radiology, 126(5), 404-408. 